\title{
PENGARUH KARAKTERISTIK KOMITE AUDIT, PERUSAHAAN DAN STRUKTUR KEPEMILIKAN TERHADAP KECURANGAN PELAPORAN KEUANGAN
}

\author{
Andrian Budi Prasetyo \\ Jurusan Akuntansi, Fakultas Ekonomika dan Bisnis, Universitas Diponegoro \\ *Email Correspoding Author : andrianbp1589@gmail.com
}

\begin{abstract}
Abstrak
Penelitian memiliki tujuan menguji pengaruh karakteristik komite audit, perusahaan dan struktur kepemilikan terhadap kemungkinan kecurangan pelaporan keuangan. Karakteristik komite audit yang diteliti adalah komite audit independen, keahlian keuangan komite audit, rapat komite audit dan masa jabatan komite audit. Karakteristik perusahaan yang diteliti adalah leverage, ukuran, tingkat pertumbuhan, dan auditor eksternal perusahaan. Struktur kepemilikan yang diteliti adalah kepemilikan manajerial dan institusional perusahaan. Penelitian menggunakan metode kuantitatif. Penelitian menggunakan data sekunder yang berasal dari daftar kasus Otoritas Jasa Keuangan (OJK) serta laporan tahunan perusahaan terdaftar Bursa Efek Indonesia (BEI). Sampel penelitian terdiri dari 15 perusahaan yang terkena sanksi OJK atas kategori peringatan VIII.G.7 dan 15 perusahaan yang tidak terkena sanksi OJK. Penelitian tidak menemukan bukti secara statistik bahwa terdapat hubungan antara variabel-variabel independen dengan kecurangan pelaporan keuangan.
\end{abstract}

Kata Kunci: komite audit, karateristik perusahaan, struktur kepemilikan, kecurangan pelaporan keuangan

\begin{abstract}
This study examines the effect of audit committee characteristics, firm characteristic and ownership structure on the likelihood of fraudulent financial reporting. Audit committee characteristics is examined by audit committee financial expertise, meetings of the audit committee and the audit committee tenure. Firm characteristic is examined by the leverage, firm size, firm's growth rate and external auditor. Ownership structure is examined by managerial ownership and institutional ownership. This research is using a quantitative methods research. This research is using secondary data that comes from the cases list of Otoritas Jasa Keuangan (OJK) and annual reports of the listed companies on the Indonesia Stock Exchange (IDX). Using a sample of 15 fraud and 15 non-fraud firms, we did not find a significant relation between the independent variabels and fraudulent financial reporting.
\end{abstract}

Keywords: audit committee, firm characteristics, ownership structur, fraudulent financial reporting.

\section{PENDAHULUAN}

Kehancuran berbagai perusahaan besar dunia, seperti Enron dan WorldCom pada tahun 2001 dan 2002 yang diakibatkan oleh kecurangan yang dilakukan oleh perusahaan-perusahaan tersebut telah menurunkan tingkat kepercayaan masyarakat terhadap kegiatan pasar modal dan profesi akuntan di seluruh dunia. Adanya kecurangan yang dilakukan berbagai perusahaan di dunia menyebabkan kerugian yang banyak bagi masyarakat. The Association of Certified Fraud Examiners (ACFE) dalam Report to the Nation (RTTN) 2016 menyatakan bahwa total kerugian yang diderita akibat terjadinya seluruh kasus kecurangan yang ada dalam kajian mereka adalah sebesar lebih dari \$ 6,3 milyar dengan rata-rata kerugian per kasus sebesar \$2,7 juta. Seluruh total kerugian kecurangan tersebut menurut ACFE terbagi menjadi tiga yaitu kecurangan karena penggelapan aset, kecurangan laporan keuangan dan korupsi.

Berdasarkan ketiga klasifikasi kecurangan tersebut, ACFE dalam RTTN 2016 menyatakan bahwa kecurangan pelaporan keuangan merupakan kecurangan yang tingkat keterjadiannya paling kecil diantara kecurangan 
lainnya yaitu sebesar kurang dari 10\% namun memiliki dampak kerugian yang paling besar yaitu dengan median sebesar \$975.000. Kecurangan pelaporan keuangan merupakan tindakan yang dilakukan secara sengaja untuk menghasilkan nilai keuangan yang memberikan tampilan seperti yang diinginkan oleh pembuat laporan keuangan, dimana hal tersebut digunakan untuk mengecoh investor dan/atau kreditor (Nurharyanto, 2011).

Tindakan kecurangan pelaporan keuangan diharapakan dapat diminimalkan dengan adanya pengawasan yang baik dari berbagai pihak. Hal ini sesuai dengan teori keagenan. Jensen dan Meckling (1976) mengungkapkan bahwa teori keagenan dimulai dari adanya suatu kontrak kerjasama diantara pihak agen dan prinsipal. Dalam sebuah perusahaan, pihak agen merupakan manajemen perusahaan yang menjalankan kegiatan operasional sehari-hari perusahaan sedangkan pihak prinsipal adalah pemilik perusahaan. Pihak pemilik dan manajemen perusahaan diasumsikan mempunyai insentif masing-masing yang dapat menimbulkan konflik kepentingan diantara keduanya.

Adanya konflik kepentingan diantara kedua pihak tersebut dapat menimbulkan asimetri informasi. manajemen perusahaan selaku pelaksana kegiatan operasional perusahaan sehari-hari, yang memiliki kepentingan pribadi untuk memaksimalkan perolehan bonus serta mempunyai kepemilikan informasi yang lebih banyak dibanding pemilik perusahaan, akan menyembunyikan informasi yang dimiliki terkait perusahaan. Salah satu cara yang dapat ditempuh investor untuk menghindari adanya asimetri informasi tersebut adalah dengan menjalankan tata kelola perusahaan dengan baik.

Tata kelola perusahaan yang efektif menurut Rezaee (2007) dapat menjalankan peran penting dalam meminimalkan masalah-masalah keagenan dan memastikan bahwa kepentingan manajemen dan pemilik perusahaan adalah sejajar. Salah satu fungsi tata kelola perusahaan adalah pengawasan. Fungsi pengawasan menurut Rezaee (2007) dijalankan oleh dewan komisaris. Dewan komisaris memiliki kewajiban untuk mengawasi manajemen untuk memastikan bahwa manajemen telah melakukan berbagai tindakan sesuai dengan kepentingan terbaik bagi pemegang saham.

Dalam menjalankan kegiatan pengawasan, dewan komisaris dapat dibantu oleh komite audit. Hal ini sesuai dengan peraturan No. IX.I.5 Lampiran Keputusan Ketua Badan Pengawas Pasar Modal dan Lembaga Keuangan (BAPEPAM-LK) No. Kep-29/PM/2004 mengenai "Pembentukan dan Pedoman Pelaksanaan Kerja Komite Audit". Peraturan tersebut menyatakan bahwa "Seluruh perusahaan yang terdaftar wajib untuk membentuk komite audit yang independen dengan salah satu anggota memiliki keahlian keuangan." Dalam menjalankan kegiatan pengawasan tersebut, komite audit diharapkan mampu berkinerja secara efektif. Efektifitas kinerja komite audit dapat diukur dengan berbagai hal seperti tingkat keahlian komite, jumlah rapat komite, dan masa jabatan komite audit. Semakin efektif kinerja komite audit diharapkan mampu mengurangi kemungkinan terjadinya kecurangan pelaporan keuangan.

Telah terdapat banyak penelitian berkaitan dengan karakteristik komite audit dan pengaruhnya pada pelaporan keuangan. Abbott dkk., (2004) telah melakukan penelitian berkaitan dengan komite audit dan pengaruhnya pada kecurangan perusahaan. Penelitian tersebut memberikan bukti bahwa perusahaan yang memiliki paling tidak satu orang anggota komite dengan latar belakang keahlian keuangan dan komite yang menjalankan rapat komite audit minimal empat kali dalam satu tahun akan lebih baik dalam proses pelaporan keuangan.

Penelitian yang dilakukan oleh Raghundan dkk., (2001) dalam Huang dan Thiruvandi (2010) memberikan bukti bahwa perusahaan yang tidak melakukan kecurangan memiliki komite audit dengan minimal satu orang 
anggota yang berlatarbelakang keuangan dan/atau akuntansi. Namun, berbeda dengan penelitian Owen-Jakson dkk., (2009) yang tidak menemukan bukti bahwa keahlian komite audit mampu menurunkan kemungkinan kecurangan pelaporan keuangan.

Karakteristik komite audit lainnya adalah rapat komite audit. Penelitian Abbott dkk., (2000) dan Owen-Jakson dkk., (2009) menemukan bukti bahwa komite audit yang melaksanakan rapat dengan frekuensi yang lebih sering mampu menurunkan keterjadian kecurangan dan salah saji atas laporan keuangan. Berkaitan dengan masa jabatan komite audit, Beasley (1996) menemukan bukti bahwa masa jabatan yang lebih pendek akan menyebabkan kinerja komite audit menjadi tidak efektif dalam kaitannya dengan pencegahan kecurangan dalam perusahaan.

Selain melalui fungsi pengawasan oleh komite audit, tata kelola perusahaan juga dipengaruhi oleh berbagai macam faktor. Penelitian ini juga menguji pengaruh dari karakteristik perusahaan seperti leverage, ukuran perusahaan, tingkat pertumbuhan perusahaan dan ukuran auditor eksternal pada kemungkinan kecurangan pelaporan keuangan. Terdapat beberapa penelitian sebelumnya berkaitan dengan peran karakteristik perusahaan terdapat kecurangan pelaporan keuangan. Deli dan Gillan (2000) telah melakukan penelitian berkaitan dengan pertumbuhan perusahaan, ukuran perusahaan, dan leverage yang digunakan sebagai proksi untuk karakteristik perusahaan. Temuan dari penelitian Deli dan Gillan (2000) adalah kemungkinan mempunyai komite audit yang sepenuhnya independen dan aktif memiliki hubungan negatif dengan tingkat peluang pertumbuhan perusahaan; dan secara positif berhubungan dengan ukuran dan leverage perusahaan. Penelitian Owen-Jakson dkk., (2009) memberikan bukti bahwa ukuran perusahaan dan tingkat pertumbuhan perusahaan mempunyai pengaruh positif terhadap kemungkinan kecurangan pelaporan keuangan; sedangkan tidak ditemukan hubungan antara leverage dan ukuran auditor eksternal terhadap kecurangan pelaporan keuangan.

Faktor lain yang mempengaruhi kemungkinan kecurangan pelaporan keuangan adalah struktur kepemilikan perusahaan. Chen dkk., (2006) menyatakan bahwa struktur kepemilikan perusahaan juga merupakan hal yang penting dalam menjelaskan keterjadian kecurangan dalam perusahaan. Penelitian ini menggunakan variabel kepemilikan manajerial dan kepemilikan institusional untuk menggambarkan struktur kepemilikan perusahaan. Berdasarkan teori keagenan, kepemilikan manajerial mampu menyejajarkan insentif yang dimiliki oleh manajemen dan pemegang saham. Apabila manajemen memiliki saham perusahaan maka manajemen akan bertindak sesuai dengan apa yang diharapkan pemegang saham (Jensen dan Meckling, 1976). Terdapat beberapa penelitian yang telah meneliti hubungan kepemilikan manajerial terhadap kecurangan pelaporan keuangan. Penelitian Deli dan Gillan (2000) dan Owen-Jakson dkk., (2009) memberikan bukti bahwa kepemilikan manajerial berpengaruh negatif terhadap kecurangan.

Kepemilikan institusional merupakan kepemilikan saham perusahaan yang dimiliki oleh institusi keuangan. Modal yang ditanamkan institusi keuangan pada sebuah perusahaan merupakan modal milik para penanam saham di institusi tersebut maka dari itu institusi keuangan akan secara ketat melakukan pengawasan terhadap perusahaan yang mereka miliki sahamnya. Sharma (2004) menemukan bukti bahwa semakin tinggi tingkat kepemilikan institusional dalam perusahaan maka akan menurunkan kemungkinan kecurangan perusahaan. Hasil berbeda diperoleh oleh Farber (2005) yang memberi bukti bahwa kepemilikan institusional tidak memilikii dampak terhadap kemungkinan kecurangan perusahaan.

Terdapatnya perbedaan hasil penelitian berkaitan dengan karakteristik komite audit, karakteristik perusahaan dan struktur kepemilikan perusahaan mendorong penelitian ini dilakukan. Penelitian ini mengacu 
Pengaruh karakteristik komite audit...

pada penelitian Owen-Jakson (2009) namun menambahkan variabel masa jabatan komite audit dan kepemilikan institusional sebagai pembeda dengan penelitian yang telah ada sebelumnya.

Penelitian ini menggunakan populasi perusahaan yang listed di BEI kecuali perusahaan yang berada di industri keuangan. Perusahaan keuangan tidak dimasukkan ke dalam penelitian karena adanya perbedaan lingkungan regulasi dibanding dengan jenis industri lainnya.

\section{TINJAUAN PUSTAKA}

\section{Teori Keagenan}

Hubungan keagenan dijelaskan oleh Jensen dan Meckling (1976) dalam teori keagenan sebagai "suatu kontrak kerjasama antara pemilik sumber daya ekonomis (principal) dan manajer (agent) yang mengelola penggunaan dan pengendalian sumber daya tersebut." Masing-masing pihak memiliki kepentingannya masing masing maka dari itu perlu adanya suatu upaya untuk mengatasi serta mengurangi masalah keagenan, hal ini menimbulkan biaya keagenan (agency cost). Biaya keagenan ini nantinya akan ditanggung oleh prinsipal dan agen. Terdapat tiga jenis biaya keaganenan yang diungkapkan oleh Jensen dan Meckling (1976) yaitu monitoring cost, bonding cost dan residual loss.

Monitoring cost merupakan biaya yang timbul dan ditanggung oleh prinsipal. Biaya tersebut digunakan untuk memonitor perilaku agen, yaitu untuk mengukur, mengamati, dan mengontrol perilaku agen. Bonding cost adalah biaya yang menjadi tanggungan agen, yang digunakan untuk menjalankan dan mematuhi mekanisme untuk menjamin bahwa agen bertindak sesuai dengan kepentingan prinsipal. Residual loss adalah sebagai biaya pengorbanan yang berupa berkurangnya kemakmuran prinsipal yang muncul karena perbedaan keputusan agen dan keputusan prinsipal.

Adanya perbedaan kepentingan diantara manajemen dan pemilik perusahaan tersebut memungkinkan manajemen untuk bertindak curang. Perlu adanya berbagai upaya untuk mengurangi kemungkinan kecurangan tersebut terjadi. Salah satu upaya untuk mengurangi kemungkinan kecurangan dalam perusahaan adalah dengan melakukan pengawasan dalam perusahan melalui pembentukan komite audit yang bertugas untuk mengawasi tindakan manajemen yang berkaitan dengan operasional perusahaan.

Selain pengawasan manajemen, karakteristik perusahaan, seperti leverage; ukuran perusahaan; tingkat pertumbuhan dan auditor eksternal, juga dianggap mampu berpengaruh terhadap kecurangan pelaporan keuangan. Owen-Jackson dkk., (2009) menyatakan bahwa tingkat utang yang semakin besar dalam struktur modal perusahaan berdampak pada semakin besarnya kegiatan monitoring dalam perusahaan tersebut. Fama dan Jensen $(1983 a, b)$ menyatakan bahwa biaya keagenan akan meningkat sesuai dengan ukuran perusahaan. Semakin besar utang dan ukuran perusahaan, maka otomatis pengawasan prinsipal terhadap agen juga akan semakin ketat. Prinsipal menerapkan pengawasan dan mekanisme pengendalian yang ketat agar agen tidak melakukan penyalahgunaan wewenang. Namun, semakin ketat pengawasan oleh prinsipal akan mengakibatkan semakin meningkatkan keinginan agen untuk bertindak curang. Salah satu bentuk kecurangan tersebut adalah dengan kecurangan pelaporan keuangan yang akan menguntungkan manajer perusahaan.

Struktur kepemilikan juga merupakan faktor yang penting dalam mengurangi kemungkinan kecurangan pada perusahaan. Deli dan Gillan (2000) menyatakan bahwa kepemilikan manajerial akan mengurangi kemungkinan kecurangan karena kepemilikan manajerial dianggap mampu menyejajarkan kepentingan antara manajer dan 
pemegang saham. Manajer yang mempunyai saham perusahaan akan bersikap sebagai pemegang saham, sehingga kepentingan manajer juga akan selaras dengan pemegang saham.

\section{Telaah Penelitian Terdahulu}

Penelitian yang meneliti keberadaan komite audit dan kejadian kecurangan menghasilkan hasil yang beragam. Beasley (1996) tidak menemukan bahwa adanya komite audit secara signifikan berdampak pada kemungkinan kecurangan laporan keuangan. Sebaliknya, Dechow dkk., (1996) dan McMullen (1996) menemukan bukti bahwa keberadaan komite audit dapat menyebabkan berkurangnya tindak kecurangan dalam perusahaan.

Hubungan karakteristik komite audit dan kualitas pelaporan keuangan telah dibahas pada berbagai penelitian sebelumnya. Abbott dkk., (2000) menguji pengaruh karakteristik komite audit pada pelaporan keuangan dengan menggunakan variabel gabungan meliputi independensi dan aktivitas komite audit. Penemuan mereka menunjukkan bahwa perusahaan yang anggota komite auditnya sepenuhnya berasal dari pihak luar dan melakukan pertemuan sedikitnya dua kali setiap tahunnya cenderung untuk tidak melakukan kecurangan dalam perusahaan.

Beasley dkk., (2000) dalam penelitiannya meneliti komposisi dan aktivitas komite audit secara terpisah, menemukan hasil signifikan yang negatif (positif) perbedaan dalam komite audit yang terdiri sepenuhnya dari pihak luar (yang bertemu tidak sering) untuk perusahaan yang curang atau tidak curang. Abbott dkk., (2004) meneliti dampak karakteristik komite audit yang diidentifikasi oleh Blue Ribbon Committee pada kemungkinan penyajian kembali keuangan. Hasil penelitian mereka menunjukkan bahwa tingkat aktivitas dan keahlian keuangan (sedikitnya satu anggota memiliki keahlian keuangan) menunjukkan hubungan negatif dengan terjadinya penyajian kembali. Dalam sebuah penelitian hubungan antara keahlian komite audit, independensi dan aktivitas dalam manajemen laba, Bedard dkk., (2004) menemukan manajemen laba yang agresif berhubungan negatif dengan keahlian tata kelola dan keuangan dari anggota komite audit, dengan independensi, dan dengan keberadaan mandat yang jelas yang mendefinisikan tanggung jawab komite.

Deli dan Gillan (2000), menggunakan pertumbuhan perusahaan, kepemilikan manajerial, ukuran perusahaan, dan leverage sebagai proksi untuk aktivitas dalam proses kontrak dan sifat yang mendasari perusahaan, menemukan bahwa kemungkinan memiliki komite audit yang sepenuhnya independen dan aktif berhubungan negatif dengan tingkat peluang pertumbuhan perusahaan dan kepemilikan manajerial; dan secara positif berhubungan dengan ukuran dan leverage perusahaan. Deli dan Gillan (2000) mengungkapkan bahwa komposisi komite audit berkembang sebagai sebuah fungsi dari sifat yang mendasari perusahaan dan lingkungan kontraknya. Oleh karena itu, pengaruh komite audit mungkin dikurangi oleh sifat yang mendasari perusahaan dan lingkungan kontraknya.

Penelitian ini mengacu pada penelitian Owen-Jackson dkk., (2009). Penelitian berusaha untuk meneliti tentang pengaruh karakteristik komite audit (jumlah rapat komite audit, keahlian keuangan komite audit dan masa jabatan komite audit), karakteristik perusahaan (leverage, ukuran perusahaan, tingkat pertumbuhan perusahaan, dan auditor eksternal perusahaan) dan struktur kepemilikan perusahaan (kepemilikan manajerial dan institusional) terhadap keterjadian kecurangan pelaporan keuangan. Penelitian ini memiliki perbedaan dibanding penelitian yang dilakukan oleh Owen-Jackson dkk., (2009) dalam hal perumusan hipotesis, dimana Owen-Jackson dkk.,(2009) hanya merumuskan 3 hipotesis saja, sedangkan penelitian ini merumuskan 9 hipotesis. Selain itu, dalam hal pengukuran variabel-variabel penelitian yaitu keahlian keuangan, rapat komite, masa jabatan dalam 
Pengaruh karakteristik komite audit...

penelitian ini menggunakan pengukuran yang berbeda dengan penelitian Owen-Jackson dkk., (2009). Perubahan pengukuran variabel-variabel tersebut bertujuan agar bisa semakin banyak dan mendalam informasi yang diperoleh dari data-data tersebut.

\section{Hipotesis Penelitian}

Jensen dan Meckling (1976) mengungkapkan bahwa dalam teori keagenan terdapat agen dan prinsipal yang memiliki kepentingan yang berbeda, maka dari itu perlu adanya pengawasan terhadap setiap tindakan manajemen perusahaan yang berkaitan dengan kegiatan operasional perusahaan sehari-hari. Pengawasan tersebut dilakukan oleh dewan komisaris yang bertindak mewakili para pemegang saham perusahaan. Dalam melakukan pengawasan, dewan komisaris dapat membentuk komite audit yang memiliki tugas untuk membantu pengawasan terhadap manajemen perusahaan.

Pengawasan tersebut juga termasuk pengawasan terhadap pelaporan keuangan. Untuk mengurangi kemungkinan terjadinya kecurangan pelaporan keuangan, dewan komisaris memberi wewenang kepada komite audit untuk melakukan pengawasan terhadap proses pelaporan keuangan. Komite audit dianggap mampu menjalankan kinerja pengawasan secara efektif apabila mempunyai anggota yang memiliki latar belakang keahlian dan kemampuan dalam bidang keuangan serta akuntansi.

Penelitian Abbott dkk., (2003) membuktikan bahwa komite audit yang mempunyai paling tidak satu anggota yang berlatarbelakang keuangan dan/atau akuntansi cenderung untuk (1) mengadakan pertemuan lebih lama dengan kepala auditor internal, (2) menyediakan akses pribadi untuk kepala auditor internal; dan (3) memeriksa proposal audit internal dan hasil-hasil audit internal. Penelitian yang dilakukan oleh Davidson dkk., (2004) memberikan bukti bahwa harga saham perusahaan bereaksi positif ketika terdapat anggota komite audit perusahaan yang mempunyai keahlian keuangan.

Penelitian Abbott dkk., (2004) juga menemukan bukti bahwa perusahaan yang memiliki minimal satu orang anggota berkeahlian keuangan dalam komite auditnya maka memiliki lebih sedikit kemungkinan berkaitan dengan restatement laporan keuangan. Adanya anggota komite audit yang memiliki keahlian keuangan komite audit dianggap dapat membantu perusahaan mengatasi tindak kecurangan pelaporan keuangan. Berdasarkan dari penjelasan tersebut maka hipotesis pertama penelitian adalah sebagai berikut:

H1 : Keahlian keuangan komite audit berpengaruh negatif terhadap kemungkinan kecurangan pelaporan keuangan.

Berdasarkan teori keagenan yang dijelaskan oleh Jensen dan Meckling (1976), mereka membagi biaya keagenan menjadi tiga. Satu diantaranya adalah biaya monitoring. Salah satu bentuk dari pelaksanaan biaya monitoring yang dikeluarkan oleh prinsipal adalah dengan melakukan pengawasan terhadap manajemen perusahaan yang dapat diwakili oleh dewan komisaris. Tujuan pengawasan tersebut untuk mengurangi kemungkinan manajer berperilaku oportunistik yang akan menimbulkan kerugian bagi pemilik perusahaan. Salah satu contoh perilaku oportunistik manajer adalah dengan melakukan manipulasi laporan keuangan.

Dalam melakukan pengawasan, dewan komisaris dapat dibantu oleh komite audit. Komite audit dalam menjalankan kegiatan pengawasannya ditunjukkan oleh kegiatan rapat yang akan terus memantau dan mengawasi proses pelaporan keuangan perusahaan. Semakin sering frekuensi rapat yang dilakukan komite audit, maka semakin kecil peluang manajer untuk memanipulasi pelaporan keuangan karena akan terus diperiksa komite audit. 
Penelitian Beasley dkk., (1999) memberikan bukti bahwa komite audit umumnya melakukan pertemuan setahun sekali. Beasley dkk., (1999) juga menemukan bahwa sebanyak 25\% perusahaan yang mengalami kecurangan tidak memiliki komite audit. Penelian Abbott dkk., (2000) menguji dua karakteristik komite audit, yaitu aktivitas dan independensi, dan kemungkinan kecurangan laporan keuangan. Penelitian tersebut memberikan bukti bahwa komite audit yang melakukan pertemuan setidaknya dua kali dalam satu tahun mempunyai hubungan dengan penurunan kemungkinan kecurangan laporan keuangan.

SEC (2002) (dalam Huang dan Thiruvadi, 2010), menyatakan bahwa untuk mengurangi berbagai resiko yang ada dalam perusahaan maka anggota komite audit sebaiknya melakukan komunikasi secara rutin mengenai masalah akuntansi dengan manajer dan auditor internal serta eksternal. Setelah periode SOX, pengendalian dan tingkat kerajinan rapat komite audit sudah menjadi faktor kunci dari kualitas komite audit. Berdasarkan penjelasan di atas maka berikut merupakan hipotesis kedua dalam penelitian ini:

H2 : Jumlah rapat komite audit berpengaruh negatif terhadap kemungkinan kecurangan pelaporan keuangan.

Teori keagenan menyatakan bahwa terdapat konflik di antara prinsipal dengan agen (Jensen dan Meckling, 1976). Apabila dalam perusahaan, prinsipal adalah pemegang saham perusahaan dan agen adalah manajer perusahaan. Dalam menjalankan tugas untuk mengelola sumber daya yang diberikan oleh pemilik perusahaan, manajemen perlu diawasi. Hal ini perlu dilakukan agar kepentingan pemilik tercapai.

Komite audit yang bekerja dibawah dewan komisaris, yang bertindak untuk mewakili kepentingan pemegang saham, mempunyai tugas dan fungsi untuk melakukan pengawasan terhadap proses pelaporan keuangan yang dilakukan oleh manajemen perusaahan. Pengawasan tersebut dilakukan untuk mencegah terjadinya tindakan manajer yang merugikan pemilik, yang dapat dilakukan dengan cara memanipulasi laporan keuangan.

Salah satu karakteristik komite audit adalah masa jabatan komite audit. Masa jabatan komite audit merupakan faktor yang mempengaruhi keefektifan pelaksanaan tugas dan fungsi komite. Chen dkk., (2006) menyatakan bahwa semakin panjang masa jabatan, maka semakin baik pula pemahaman atas perusahaan. Hal ini juga berarti semakin baik pula pengetahuan mengenai karakter para manajer yang diawasi. Pemahaman dan pengetahuan tersebut menyebabkan semakin lama masa jabatan komite audit maka semakin sulit bagi manajer untuk mengelabuhi komite audit.

Penelitian Beasley (1996) memberikan bukti secara statistik bahwa apabila dibandingkan dengan perusahaan yang tidak curang, perusahaan yang melakukan kecurangan memiliki rata-rata masa jabatan yang lebih kecil. Anggota komite audit yang memiliki masa jabatan lebih pendek dianggap kurang berpengalaman atas perusahaan sehingga menyebabkan berkinerja secara kurang efektif. Berdasarkan penjelasan yang telah diuraikan tersebut maka hipotesis ketiga dalam penelitian adalah sebagai berikut:

H3 : Masa jabatan komite audit berpengaruh negatif terhadap kemungkinan kecurangan pelaporan keuangan.

Teori akuntansi positif menyatakan bahwa apabila perusahaan mempunyai rasio leverage besar, maka direksi memiliki kecenderungan untuk menjalankan kebijakan akuntansi yang bertujuan untuk mengecilkan rasio leverage perusahaan. Salah satu cara yang dapat ditempuh untuk mengecilkan rasio leverage adalah dengan menggeser laba periode mendatang ke periode saat ini (Watts dan Zimmerman, 1986). Penggeseran laba dilakukan sebagai tindakan antisipasi terhadap terjadinya default technic. Dalam memberikan utang kepada perusahaan, kreditor selalu memberi syarat pada perusahaan untuk mempertahankan serta mematuhi tingkat 
Pengaruh karakteristik komite audit...

rasio leverage. Demi untuk menghindari keadaan dimana perusahaan tidak dapat memperoleh pinjaman lagi dari kreditor dan pembatasan pemberian deviden terhadap pemegang saham, maka direksi lebih memilih untuk menjalankan kebijakan akuntansi yang menghasilkan rasio leverage yang lebih kecil.

Jensen dan Meckling (1976) menyatakan bahwa pemilik, yang bertindak dalam kepentingan ekonomi dirinya sendiri, mempunyai kepentingan untuk memindahkan kekayaan dari penggugat tetap menuju diri mereka sendiri. Semakin tinggi tingkat utang pada struktur modal perusahaan, maka semakin tinggi permintaan untuk dilakukannya pengawasan. Hal tersebut memberikan konflik kepentingan dalam lingkungan kontrak, konflik kepentingan terjadi pada kreditor (prinsipal) dan perusahaan sebagai debitur (agen).

Kreditor mempunyai insentif supaya pokok dan bunga utang mereka dibayar lunas oleh perusahaan, di sisi lain, manajemen perusahaan selaku debitur, mempunyai insentif untuk mendapatkan pinjaman lagi dari kreditor dan memberikan deviden kepada pemegang saham mereka. Berdasarkan dari penjelasan tersebut maka hipotesis keempat penelitian ini adalah sebagai berikut:

H4 : Leverage perusahaan berpengaruh positif terhadap kemungkinan kecurangan pelaporan keuangan.

Teori akuntansi menyatakan bahwa besarnya biaya politik sebuah perusahaan dapat diproksikan oleh ukuran perusahaan (Watts dan Zimmerman, 1986). Perusahaan berbiaya politik besar lebih sensitif dalam kaitannya dengan transfer kemakmuran yang mungkin lebih besar dibandingkan dengan perusahaan berbiaya politik lebih kecil. Hal ini berarti, perusahaan besar memiliki kecenderungan untuk menurunkan atau mengurangi laba yang dilaporkan dalam laporan keuangan perusahaan dibanding dengan perusahaan kecil. Profitabilitas perusahaan yang tinggi akan menyebabkan peningkatan suhu politik dan dapat menyebakan regulasi atau pajak baru.

Fama dan Jensen (1983a,b) menemukan bahwa terdapat kecenderungan biaya agensi yang meningkat sejalan dengan ukuran perusahaan. Adanya kenaikan biaya agensi akan mengakibatkan kenaikan kebutuhan untuk pengawasan dan mekanisme pengendalian lainnya. Adanya peningkatan pengawasan dan pengendalian juga berdampak pada peningkatan konflik kepentingan yang terjadi antara prinsipal dan agen, dimana dalam hal ini agen adalah perusahaan sedangkan prinsipal adalah pemerintah dimana perusahaan beroperasi.

Semakin besar ukuran perusahaan maka akan semakin besar pula usahanya untuk mengecilkan laba. Hal ini dilakukan perusahaan agar tidak ada regulasi atau pajak baru yang akan ditetapkan bagi perusahaan. Cara yang ditempuh perusahaan dalam rangka mengecilkan laba adalah dengan menangguhkan laba periode saat ini ke laba periode di masa mendatang. Salah satu bentuk mengecilkan laba lainnya dapat dilakukan dengan memanipulasi laporan keuangan. Perusahaan dengan ukuran yang besar juga dilihat dari kompleksitas transaksi dalam perusahaan maka ketika pada suatu perusahaan semakin kompleks transaksinya maka akan meningkatkan kemungkinan terjadinya kecurangan pelaporan keuangan. Berdasarkan penjelasan yang telah diuraikan berikut merupakan hipotesis kelima dalam penelitian ini:

H5 : Ukuran perusahaan berpengaruh positif terhadap kemungkinan kecurangan pelaporan keuangan.

Teori akuntansi positif menyatakan bahwa program bonus digunakan direksi perusahaan untuk keuntungan bagi dirinya sendiri. Direksi cenderung untuk menjalankan kebijakan akuntansi yang memungkinkan mereka untuk memperoleh bonus yang maksimal. Hal tersebut dilakukan dengan cara menggeser laba periode mendatang ke periode sekarang, yang berakibat pada laba periode sekarang yang lebih besar dibandingkan laba sebenarnya. 
Watts dan Zimmerman (1986) menyatakan bahwa kontrak menjadi lebih efektif ketika tidak terdapat kendala pada bagaimana jumlah yang digunakan dalam kontrak dikalkulasi. Dalam kaitanya dengan rencana kompensasi yang didasarkan pada perolehan laba perusahaan, mereka berpendapat bahwa "apabila pemberian penghargaan kepada manajer untuk alasan insentif menggunakan kompensasi yang didasarkan pada laba maka harus ada pembatasan pada metode yang digunakan manajer dalam menghitung laba. Berdasarkan penjelasan tersebut maka hipotesis keenam dalam penelitian ini adalah sebagai berikut:

H6 : Tingkat pertumbuhan perusahaan berpengaruh positif terhadap kemungkinan kecurangan pelaporan keuangan.

Teori keagenan menjelaskan bahwa ada perbedaan kepentingan diantara agen dan prinsipal (Jensen dan Meckling, 1976). Perlu adanya mekanisme tata kelola perusahaan untuk menyejajarkan kepentingan di antara manajer dan pemegang saham. Salah satu fungsi tata kelola perusahaan adalah fungsi auditor eksternal. Rezaee (2007) menyatakan bahwa fungsi audit eksternal diperlukan oleh perusahan publik. Auditor eksternal diharapkan dapat bertindak secara independen dalam membuat opini atas laporan keuangan perusahaan.

Auditor yang menjalankan verifikasi atas laporan keuangan secara independen diharapkan mampu membantu manajer untuk menyediakan laporan keuangan yang berkualitas baik. Penelitian sebelumnya telah menunjukkan bahwa KAP Big 4 mampu berkontribusi dalam mengurangi keterjadian kecurangan pelaporan keuangan. Auditor Big 4 diasumsikan memiliki Sumber Daya Manusia yang bagus serta sistem kerja yang sesuai dengan standar audit yang ada. Sehingga, ketika suatu perusahaan diaudit oleh KAP Big 4 maka diasumsikan perusahaan takut untuk melakukan kecurangan. Untuk itu akan dihipotesiskan sebagai berikut:

\section{H7: Auditor Eksternal (Big 4) berpengaruh negatif terhadap kecurangan pelaporan keuangan}

Teori keagenan menunjukkan bahwa kepemilikan manajerial mampu menyejajarkan insentif manajemen dan pemegang saham (Jensen dan Meckling, 1976). Owen-Jackson dkk., (2009) menyatakan apabila manajer dalam suatu perusahaan memiliki sendiri saham persusahaan tersebut maka ia akan lebih mementingkan kinerja jangka panjang perusahaan. Manajer perusahaan yang memiliki saham perusahaan dimana ia bekerja mungkin akan membuat keputusan terbaik sesuai dengan apa yang diharapkan pemilik perusahaan, hal ini karena manajemen juga merupakan pemilik saham perusahaan.

Deli dan Gillan (2000) menyatakan bahwa kepemilikan manajerial mampu membuat insentif manajemen dan pemegang saham menjadi selaras, sehingga dengan adanya kepemilikan manajerial di perusahaan akan menurunkan tingkat kemungkinan keterjadian kecurangan pelaporan keuangan. Manajer yang mempunyai saham perusahaan akan menjadi pemilik perusahaan. Adanya kepemilikan manajerial tersebut menyebabkan ketidakselarasan kepentingan manajemen dan pemegang saham, menjadi selaras. Hal tersebut juga diharapkan mampu menyebabkan berkurangnya kecurangan yang dilakukan oleh manajer yang digunakan untuk mensejahterakan dirinya sendiri. Salah satu bentuk kecurangan yang dapat dijalankan oleh manajemen perusahaan adalah kecurangan pelaporan keuangan. Berdasarkan pada penjelasan tersebut berikut merupakan hipotesis kedepelapan dalam penelitian ini:

H8 : Kepemilikan manajerial berpengaruh negatif terhadap kemungkinan kecurangan pelaporan keuangan.

Teori agen-prinsipal menunjukkan bahwa kepemilikan institusi merupakan kepemilikan yang dimiliki oleh intitusi keuangan (finance). Dimana pada dasarnya kepemilikan institusi menggunakan modal para penanam modal di perusahaan institusi dan kemudian institusi keuangan sebagai penghimpun modal melakukan investasi 
pada suatu perusahaan. Karena merupakan kumpulan uang dari para penanam modal, maka institusi keuangan akan melakukan pengawasan yang ketat terhadap operasi maupun laporan yang dihasilkan oleh perusahaan karena untuk melindungi modal yang mereka investasikan tadi. Untuk itu hipotesis kedelapan adalah sebagai berikut :

H9 : Kepemilikan institusi berpengaruh negatif terhadap kemungkinan kecurangan pelaporan keuangan

\section{METODE PENELITIAN}

\section{Populasi dan Sampel}

Populasi penelitian ini adalah seluruh perusahaan yang terdaftar dalam BEI pada tahun 2010-2013. Tahun 2010-2013 digunakan karena untuk keterbaruan data yang digunakan. Data yang digunakan hanya sampai pada tahun 2013 karena adanya keterbatasan data yang diperoleh dari OJK dan BEI. Metode purposive sampling digunakan untuk pemilihan sampel dalam penelitian ini. Berikut merupakan kriteria-kriteria yang digunakan dalam pengambilan sampel: perusahaan non-keuangan yang terdaftar di BEI tahun 2010-2013; dan perusahaan memiliki data yang diperlukan untuk penelitian, dimana data diperoleh dalam laporan tahunan perusahaan.

Selanjutnya, sampel diambil secara berpasangan antara perusahaan yang dikenai sanksi oleh OJK dengan kategori peringatan VIII.G.7 dengan perusahaan yang tidak dikenai sanksi oleh OJK. Untuk perusahaan yang tidak dikenai sanksi oleh OJK harus memiliki kesamaan dalam bidang industri serta besaran asetnya dengan perusahaan yang dikenai sanksi oleh OJK.

Tabel 1. Definisi Operasional Variabel

\begin{tabular}{|c|c|c|}
\hline No & Nama Variabel & Pengukuran \\
\hline 1 & $\begin{array}{l}\text { Kecurangan pelaporan } \\
\text { keuangan }\end{array}$ & $\begin{array}{l}\text { Memberi nilai "1" jika ada kejadian kecurangan dalam hal ini termasuk dalam laporan kasus } \\
\text { yang dikeluarkan oleh OJK atas kategori peringatan VIII.G.7 dan nilai "0" jika tidak terkena } \\
\text { sanksi atas kategori peringatan tersebut. }\end{array}$ \\
\hline 2 & $\begin{array}{l}\text { Keahlian keuangan } \\
\text { komite audit }\end{array}$ & $\begin{array}{l}\text { Persentase jumlah anggota komite audit yang mempunyai latar belakang pendidikan dan } \\
\text { pengalaman dalam bidang akuntansi dan/atau keuangan terhadap total keseluruhan anggota } \\
\text { komite audit. }\end{array}$ \\
\hline 3 & Rapat komite audit & $\begin{array}{l}\text { Persentase dengan jumlah rapat/pertemuan yang diselenggarakan oleh komite audit selama } \\
\text { tahun pelaporan terhadap minimal rapat/pertemuan yang disarankan oleh Komite Nasional } \\
\text { Good Corporate Governance. }\end{array}$ \\
\hline 4 & $\begin{array}{l}\text { Masa jabatan komite } \\
\text { audit }\end{array}$ & $\begin{array}{l}\text { Persentase jumlah anggota komite audit yang menjabat dua periode berturut-turut terhadap } \\
\text { total keseluruhan anggota komite audit. }\end{array}$ \\
\hline 5 & Leverage & Rasio total utang jangka panjang terhadap total ekuitas pemegang saham. \\
\hline 6 & Ukuran perusahaan & Logaritma natural dari nilai buku total aset perusahaan. \\
\hline 7 & Tingkat pertumbuhan & $\begin{array}{l}\text { Menghitung perubahan atau selisih antara penjualan tahun sekarang dengan tahun sebelumnya } \\
\left.\text { terhadap penjualan tahun sebelumnya ((St-St-1)/ } \mathrm{St}_{-1}\right) \text {. }\end{array}$ \\
\hline 8 & $\begin{array}{l}\text { Ukuran Kantor } \\
\text { Akuntan Publik (KAP) }\end{array}$ & Memberi nilai “1" jika termasuk KAP 4 besar dan memberi nilai "0" jika tidak. \\
\hline 9 & $\begin{array}{l}\text { Kepemilikan } \\
\text { manajerial }\end{array}$ & Menjumlah persentase kepemilikan saham dari direksi. \\
\hline 10 & $\begin{array}{l}\text { Kepemilikan } \\
\text { Institusional }\end{array}$ & ilikan saham dari institusi keuangan. \\
\hline
\end{tabular}

\section{HASIL DAN PEMBAHASAN}

\section{Deskripsi Objek Penelitian}

Objek penelitian ini merupakan seluruh perusahaan yang terdaftar dalam BEI pada tahun 2010-2013. Penelitian ini menggunakan metode purposive sampling dalam pemilihan sampel. Dimana berdasarkan daftar kasus dengan kategori peringatan VIII.G.7 selama tahun 2010-2013 yang dikeluarkan oleh OJK terdapat 20 perusahaan yang terkena kasus terkait penyajian laporan keuangan. Berdasarkan 20 perusahaan tersebut, sebanyak tiga perusahaan tidak dapat diakses laporan keuangannya dan dua perusahaan menggunakan mata 
uang dolar dalam pelaporan keuangannya sehingga dikeluarkan dari sample penelitian. Berikut rincian mengenai seleksi sampel untuk penelitian:

Tabel 2. Perincian Sampel

\begin{tabular}{|c|c|}
\hline Kriteria & Jumlah \\
\hline $\begin{array}{l}\text { Perusahaan melakukan kecurangan pelaporan } \\
\text { keuangan }\end{array}$ & 20 \\
\hline $\begin{array}{l}\text { Perusahaan yang tidak dapat diakses laporan } \\
\text { keuangannya }\end{array}$ & (3) \\
\hline Laporan keuangan menggunakan mata uang dolar & $(2)$ \\
\hline Total perusahaan curang yang termasuk sampel & 15 \\
\hline
\end{tabular}

Sumber : Data yang diolah, 2016

Kemudian diambil pasangan untuk masing-masing perusahaan yang terkena sanksi OJK untuk sampel bagi perusahaan yang tidak melakukan kecurangan pelaporan keuangan. Perusahaan yang menjadi pasangan bagi sampel perusahaan yang terkena kasus penyajian laporan keuangan harus memiliki kriteria kesamaan dalam jenis industri dan besaran asetnya. Berdasarkan hal tersebut maka diperoleh sampel akhir sebanyak 30 perusahaan yang terdiri dari 15 perusahaan yang dikenai sanksi oleh 0JK dan 15 perusahaan yang tidak terkena sanksi oleh OJK.

\section{Hasil Penelitian}

Tabel 3. Hasil Regresi Logistik

\begin{tabular}{lcccc}
\hline \multicolumn{1}{c}{ Variabel } & Prediksi Arah & $\begin{array}{c}\text { Nomor } \\
\text { Hipotesis }\end{array}$ & Koefisien & Signifikansi \\
\hline Keahlian Keuangan & - & 1 & $-2,375$ & 0,305 \\
\hline Rapat Komite & - & 2 & $-0,016$ & 0,822 \\
\hline Masa Jabatan & - & 3 & 2,337 & 0,317 \\
\hline Leverage & + & 4 & 0,146 & 0,701 \\
\hline Ukuran Perusahaan & + & 5 & $-1,419$ & 0,140 \\
\hline $\begin{array}{l}\text { Tingkat } \\
\text { Pertumbuhan }\end{array}$ & + & 6 & 3,241 & 0,106 \\
\hline Auditor Eksternal & - & 7 & $-0,199$ & 0,148 \\
\hline $\begin{array}{l}\text { Kepemilikan } \\
\text { Manajerial }\end{array}$ & - & 8 & $-0,206$ & 0,347 \\
\hline Kepemilikan Institusi & - & 9 & 0,023 & 0,399 \\
\hline
\end{tabular}

\section{Pengaruh Keahlian Keuangan Komite Audit Terhadap Kecurangan Pelaporan Keuangan}

Hipotesis pertama dalam penelitian ini menyatakan bahwa keahlian keuangan komite audit memiliki pengaruh negatif terhadap kemungkinan kecurangan pelaporan keuangan. Berdasar kepada hasil uji regresi logistik di tabel 3 dapat ditarik kesimpulan bahwa hipotesis pertama tidak diterima. Dapat diartikan bahwa keahlian keuangan komite audit tidak memiliki pengaruh terhadap keterjadian kecurangan pelaporan keuangan secara signifikan. Kemungkinan alasan dibalik hasil penelitian tersebut adalah bahwa terdapat peraturan nomer IX.I.5 yang dikeluarkan oleh BAPEPAM yang mensyaratkan adanya minimal satu anggota komite audit merupakan ahli di bidang keuangan. Hal ini menyebabkan kurang adanya pengaruh dari keahlian keuangan komite audit terhadap kecurangan laporan keuangan karena semua perusahaan diwajibkan memiliki ahli keuangan dalam susunan komite auditnya sehingga tidak ada pembeda antara perusahaan yang benar-benar memanfaatkan keahlian keuangan pada komite audit dengan perusahaan yang hanya menjalankan kewajiban berdasarkan peraturan yang berlaku.

Hasil penelitian tidak mendukung penelitian Abbott dkk., (2004); Xie dkk., (2003); dan Wardhani dan Joseph (2010) dan yang memberi bukti bahwa komite audit yang memiliki minimal satu anggota dengan latar belakang keuangan atau akuntansi akan mampu menurunkan kemungkinan perusahaan dalam melaporkan laporan keuangan yang tidak berkualitas. Hasil penelitian ini mendukung penelitian yang dilakukan oleh Kusumastuti dkk., (2007); Pamudji dan Trihartati (2009); dan Rustiarini (2012) yang menemukan bukti bahwa komite audit 
Pengaruh karakteristik komite audit...

yang memiliki latar belakang akuntansi dan/atau keuangan tidak memiliki pengaruh pada kualitas laporan keuangan perusahaan.

\section{Pengaruh Jumlah Rapat Komite Audit Terhadap Kecurangan Pelaporan Keuangan}

Hipotesis kedua dalam penelitian ini menyatakan bahwa jumlah rapat komite audit mempunyai pengaruh negatif terhadap kemungkinan kecurangan pelaporan keuangan. Didasarkan pada hasil uji regresi logistik pada tabel 3 maka dapat disimpulkan bahwa hipotesis kedua tidak diterima. Hal ini dapat diartikan bahwa jumlah rapat komite audit tidak mempunyai pengaruh pada terjadinya kecurangan pelaporan keuangan pada perusahaan.

Jumlah rapat komite audit yang semakin intens tidak menjamin bahwa komite audit akan berkinerja secara efektif dalam menghindari kemungkinan kecurangan pelaporan keuangan. Alasan yang mungkin menjadi penjelas dari hasil temuan ini adalah karena semua kegiatan rapat yang dilakukan oleh komite audit tersebut membutuhkan tindak lanjut dari dewan komisaris maka apabila dewan komisaris tidak menindaklanjuti saran komite audit tersebut, pada akhirnya rapat komite audit tersebut tidak berdampak apa-apa pada pendekteksian kecurangan pelaporan keuangan.

Kemungkinan alasan lain berkaitan dengan hasil temuan ini adalah bahwa komite audit tidak mampu mendeteksi adanya kemungkinan kecurangan hanya dengan melalui rapat semata. Temuan audit berkaitan dengan indikasi terjadinya kecurangan pelaporan keuangan perlu diperoleh oleh komite audit melalui audit operasional perusahaan. Dalam melakukan rapat, komite audit seharusnya juga menyertakan dewan komisaris dan manajemen perusahaan sehingga berbagai masalah berkaitan dengan proses laporan keuangan diketahui oleh komite audit dan dapat diberikan penyelesaiannya.

Hasil temuan penelitian tidak sejalan dengan hasil penelitian Abbott dkk., (2000; 2004) dan Beasley dkk., (1999) yang menemukan bukti bahwa komite audit yang lebih intens dalam melakukan pertemuan akan berpengaruh pada meningkatnya kualitas laporan keuangan perusahaan namun hasil penelitian ini mendukung juga penemuan Johnson dkk., (2005), Mustafa dan Meier (2006) dan Ismiyanti dan Prastichia (2015) yang menyatakan bahwa rapat komite audit tidak signifikan pengaruhnya terhadap kecurangan pelaporan keuangan.

\section{Pengaruh Masa Jabatan Komite Audit Terhadap Kecurangan Pelaporan Keuangan}

Hipotesis ketiga dalam penelitian ini menyatakan bahwa masa jabatan komite audit mempunyai pengaruh negatif pada kemungkinan kecurangan pelaporan keuangan. Pada tabel 3 yang merupakan tabel hasil uji regresi logistik, dapat disimpulkan bahwa hipotesis ketiga tidak diterima. Hal ini berarti bahwa secara statistik lama masa jabatan komite audit tidak berhubungan dengan kecurangan pelaporan keuangan.

Hasil penelitian ini tidak mendukung temuan dari Beasley (1996) dan Chen dkk., (2006) yang menemukan bahwa semakin lama masa jabatan anggota direksi maka akan mampu mengurangi kemungkinan terjadinya kecurangan pelaporan keuangan. Disisi lain, hasil penelitian ini mendukung temuan Johnson dkk. (2005) dan Ismiyanti dan Prastichia (2015) yang menemukan bahwa masa jabatan tidak berhubungan secara signifikan terhadap kecurangan pelaporan keuangan. Menurut Ismiyanti dan Prastichia (2015) kemungkinan alasan bahwa masa jabatan tidak berpengaruh terhadap kecurangan pelaporan keuangan adalah karena pergantian komite audit bisa saja terjadi bukan karena terjadinya suatu kecurangan pelaporan keuangan, namun bisa saja terjadi karena kecocokan antara komite audit dengan dewan komisaris perusahaan. Sehingga menyebabkan dewan komisaris mempertahankan anggota komite audit tersebut. 


\section{Pengaruh Leverage Perusahaan Terhadap Kecurangan Pelaporan Keuangan}

Hipotesis keempat dari penelitian ini mengungkapkan bahwa leverage perusahaan memiliki pengaruh positif pada kemungkinan kecurangan pelaporan keuangan. Dari hasil uji regresi logistik pada tabel 3, kesimpulan yang dapat ditarik adalah hipotesis keempat tidak dapat diterima. Dapat diartikan bahwa rasio leverage tidak memiliki hubungan dengan keterjadian kecurangan pelaporan keuangan.

Kemungkinan argumen yang menjadi penjelas atas hasil tersebut adalah bahwa pengawasan dari debtholder tidak cukup efektif untuk menghindari adanya kecurangan pelaporan keuangan yang hendak dilakukan oleh manajemen perusahaan. Hal ini mengakibatkan adanya leverage dalam perusahaan tidak mampu secara efektif menghindarkan perusahaan pada kemungkinan kecurangan pelaporan keuangan. Hasil penelitian ini sejalan dengan hasil penelitian yang dilakukan oleh Soselisa dan Mukhlasin (2008), Skousen (2009) dan Suyanto (2009) yang juga memberikan bukti bahwa leverage perusahaan tidak memiliki pengaruh pada keterjadian kecurangan pelaporan keuangan.

\section{Pengaruh Ukuran Perusahaan Terhadap Kecurangan Pelaporan Keuangan}

Hipotesis kelima pada penelitian ini mengungkapkan bahwa ukuran perusahaan memiliki pengaruh positif pada kecurangan pelaporan keuangan. Tabel 3 yang menunjukkan hasil uji regresi logistik memberikan kesimpulan bahwa hipotesis kelima tidak dapat diterima. Hal ini berarti bahwa ukuran aset perusahaan tidak memiliki pengaruh pada kejadian kecurangan pelaporan keuangan.

Kemungkinan alasan yang dapat digunakan untuk mendukung temuan ini adalah perusahaan pada berbagai ukuran yang dilihat dari ukuran asetnya memiliki kemungkinan untuk melakukan kecurangan berkaitan dengan pelaporan keuangan. Sehingga ukuran perusahaan menjadi tidak memiliki pengaruh yang signifikan terhadap kecurangan pelaporan keuangan. Hasil penelitian ini sesuai dengan penelitian Anisa (2012) dan Hapsari (2014) yang menemukan hasil bahwa ukuran perusahaan tidak memiliki pengaruh secara signifikan terhadap terjadinya kecurangan laporan keuangan. Namun, hasil penelitian ini tidak mendukung penelitian yang telah dilakukan oleh Fama dan Jensen (1983a,b) yang memberi bukti bahwa biaya agensi akan meningkat sejalan dengan ukuran perusahaan.

\section{Pengaruh Tingkat Pertumbuhan Perusahaan Terhadap Kecurangan Pelaporan Keuangan}

Hipotesis keenam penelitian ini mengungkapkan bahwa tingkat pertumbuhan perusahaan memiliki pengaruh positif terhadap kecurangan pelaporan keuangan. Tabel 3 menujukkan bukti bahwa hipotesis keenam penelitian ini tidak dapat diterima. Dapat diartikan bahwa tingkat pertumbuhan perusahaan tidak berpengaruh terhadap tindakan kecurangan pelaporan keuangan.

Temuan penelitian ini tidak mendukung teori akuntansi positif yang menyatakan bahwa semakin tinggi tingkat pertumbuhan perusahaan maka akan berakibat pada terjadinya kemungkinan kecurangan pelaporan keuangan. Hal ini muncul sebagai akibat dari metode akuntansi yang dipilih oleh manajemen yang ingin memaksimalkan kepentingan bagi dirinya sendiri melalui perolehan bonus yang besar dengan cara menggeser laba periode mendatang ke periode sekarang. Temuan penelitian ini sesuai dengan hasil penelitian yang dilakukan oleh Nabila (2013); Hapsari (2014); dan Nugraha dan Henny (2015) yang menemukan bahwa tingkat pertumbuhan perusahaan yang dilihat dari perubahan penjualan tahun ini dibandingkan tahun lalu tidak berpengaruh secara signifikan terhadap terjadinya kecurangan pelaporan keuangan. 


\section{Pengaruh Auditor Eksternal Terhadap Kecurangan Pelaporan Keuangan}

Hipotesis ketujuh penelitian ini mengungkapkan bahwa auditor eksternal berpengaruh negatif pada kecurangan pelaporan keuangan. Seperti nampak pada tabel 3, dapat diambil kesimpulan bahwa hipotesis ketujuh tidak diterima. Hal ini berarti bahwa auditor eksternal tidak akan mempengaruhi secara signifikan terhadap tindakan kecurangan pelaporan keuangan.

Kemungkinan alasan dari temuan penelitian tersebut adalah bahwa auditor eksternal merupakan auditor yang disewa perusahaan untuk melakukan tugas memeriksa laporan keuangan perusahaan dan menyatakan pendapat atas laporan keuangan. Didalam laporan auditan disampaikan bahwa laporan keuangan merupakan tanggung jawab manajemen, sedangkan tanggung jawab auditor eksternal adalah menyatakan suatu opini atas laporan keuangan perusahaan yang didasarkan pada kegiatan audit mereka. Hal ini memungkinkan auditor eksternal dalam pelaksanaan auditnya tidak menemukan adanya kecurangan laporan keuangan. Sehingga auditor eksternal tidak mempengaruhi secara signifikan terhadap terjadinya kecurangan pelaporan keuangan. Argument lain yang dapat menjelaskan hasil penelitian tersebut adalah bahwa auditor eksternal tidak sepenuhnya ada dalam setiap kegiatan operasional perusahaan. Sehingga mungkin tidak dapat memberi keyakinan seratus persen mengenai ada tidaknya kecurangan laporan keuangan yang menyebabkan auditor eksternal tidak berpengaruh terhadap kecurangan laporan keuangan.

Temuan ini sesuai dengan hasil penelitian Chen dkk., (2006), Law (2011), dan Ismiyanti dan Prastichia (2015) yang menemukan bahwa auditor eksternal tidak memiliki pengaruh terhadap terjadinya kecurangan pelaporan keuangan.

\section{Pengaruh Kepemilikan Manajerial Terhadap Kecurangan Pelaporan Keuangan}

Pernyataan hipotesis kedelapan adalah bahwa kepemilikan manajerial memiliki pengaruh negatif pada kecurangan pelaporan keuangan. Pada tabel 3, terdapat hasil uji regresi logistik yang memberi bukti bahwa hipotesis kedelapan tidak dapat diterima. Dapat disimpulkan bahwa kepemilikan manajerial tidak mempengaruhi keterjadian kecurangan pelaporan keuangan.

Temuan penelitian sesuai dengan hasil penelitian dari Nabila (2013) dan Rahmanti (2013) yang menemukan bahwa kepemilikan manajerial tidak berpengaruh secara signifikan terhadap terjadinya kecurangan pelaporan keuangan perusahaan. Namun, hasil penelitian ini tidak mendukung hasil penelitian yang diperoleh Deli dan Gillan (2000), dimana kepemilikan manajerial mampu menyejajarkan kepentingan manajemen dengan pemegang saham, sehingga dengan adanya kepemilikan manajerial mampu menurnkan kemungkinan kecurangan pelaporan keuangan perusahaan.

\section{Pengaruh Kepemilikan Institusional Terhadap Kecurangan Pelaporan Keuangan}

Hipotesis kesembilan penelitian ini menyatakan bahwa kepemilikan institusional berpengaruh negatif pada kecurangan pelaporan keuangan. Pada tabel 3, terdapat hasil uji regresi logistik yang memberi bukti bahwa hipotesis kesembilan tidak dapat diterima. Dapat diartikan bahwa kepemilikan institusional tidak mempengaruhi tindakan kecurangan pelaporan keuangan.

Kemungkinan argumen dari hasil penelitian tersebut adalah bahwa institusi keuangan yang memiliki saham di perusahaan mungkin tidak sepenuhnya dalam menjalankan pengawasan kegiatan operasional perusahaan, sehingga ada tidaknya kepemilikan institusional tidak memiliki pengaruh terhadap terjadinya kecurangan pelaporan keuangan. Temuan ini sesuai dengan hasil penelitian yang dilakukan oleh Sari (2009), Praditia (2010), 
Saffudin dan Prasetiono (2012) dan Rice (2013) yang membuktikan bahwa secara statistik kepemilikan institusional tidak memiliki pengaruh pada keterjadian kecurangan pelaporan keuangan.

\section{KESIMPULAN DAN SARAN}

\section{Kesimpulan}

Penelitian ini bertujuan untuk meneliti pengaruh karakteristik komite audit, karakteristik perusahaan dan struktur kepemilikan terhadap terjadinya kecurangan pelaporan. Terdapat 10 variabel independen yang diuji dalam penelitian ini yang terdiri dari kecurangan pelaporan keuangan (FRAUD), keahlian keuangan komite audit (AK), rapat komite audit (RK), masa jabatan komite audit (MJ), leverage (LEV), ukuran perusahaan (SIZE), tingkat pertumbuhan (GROWTH), auditor eksternal (KAP) kepemilikan manajerial (MO), dan kepemilikan institusional (IO). Metode analisis regresi logistik digunakan dalam penelitian ini. Total sampel pada penelitian ini adalah sebesar 30. Berdasarkan hasil uji hipotesis yang telah dilakukan, berikut merupakan kesimpulan penelitian ini: (1) keahlian keuangan komite audit tidak mempunyai pengaruh signifikan pada kemungkinan kecurangan pelaporan keuangan; (2) jumlah rapat komite audit tidak mempunyai pengaruh signifikan pada kemungkinan kecurangan pelaporan keuangan; (3) masa jabatan komite audit tidak mempunyai pengaruh signifikan pada kemungkinan kecurangan pelaporan keuangan; (4) leverage perusahaan tidak mempunyai pengaruh signifikan pada kemungkinan kecurangan pelaporan keuangan; (5) ukuran perusahaan tidak berpengaruh signifikan terhadap kemungkinan kecurangan pelaporan keuangan; (6) tingkat pertumbuhan perusahaan tidak mempunyai pengaruh signifikan pada kemungkinan kecurangan pelaporan keuangan; (7) ukuran auditor eksternal tidak mempunyai pengaruh signifikan pada kecurangan pelaporan keuangan; (8) kepemilikan manajerial tidak mempunyai pengaruh signifikan pada kemungkinan kecurangan pelaporan keuangan; dan (9) kepemilikan institusi tidak mempunyai pengaruh signifikan pada kemungkinan kecurangan pelaporan keuangan

\section{Saran}

Berdasarkan hasil analisis penelitian, proksi untuk variabel kecurangan pelaporan keuangan yang diukur hanya berdasarkan pada sanksi OJK dengan kategori peringatan VIII.G.7 mungkin masih dianggap kurang menggambarkan keterjadian kecurangan pelaporan keuangan. Penelitian di masa mendatang sebaiknya mencari pengukuran lain berkaitan dengan kecurangan pelaporan keuangan yang tidak hanya mengandalkan data dari instansi tertentu. Hasil penelitian yang tidak memberikan bukti mengenai pengaruh seluruh variabel independen terhadap variabel dependen membutuhkan penelitian yang lebih lanjut. Hal ini dimungkinkan akibat terlalu kecilnya sampel penelitian. Peneliti di masa mendatang diharapkan dapat menambah jangka waktu penelitian sehingga memperoleh sampel perusahaan penelitian yang lebih banyak.

\section{DAFTAR PUSTAKA}

Abbott,L.J., Y.Park, dan S.Parker. 2000. The Effects of Audit Committee Activity and Independence on Corporate Fraud. Managerial Finance 26(11):55-67.

Abbott,L.J., Susan Parker, Gary F Peters, dan K Raghunandan. 2003. The Association between Audit Committee Characteristics and Audit Fees. Auditing: A Journal ofPractice and Theory. 22, 2; hal. 17.

Abbott, L.J., S. Parker, dan G. Peters. 2004. Audit Committee Characteristics and Restatements. Auditing: A Journal ofPractice and Theory 23(1):69-87.

Association of Certified Fraud Examiners. 2016. Report to the Nation on Occupational Fraud and Abuse. 
Anisa, Widya Nur. 2012. Pengaruh Financial Expertise of Committee Audit Members, Kepemilikan Manajerial, Ukuran Perusahaan, dan Leverage terhadap Terjadinya Kecurangan Pelaporan Keuangan. Skripsi S1, Fakultas Ekonomika dan Bisnis, Univeristas Diponegoro.

Beasley,M.S. 1996. An Empirical Analysis of The Relation Between The Board of Director Composition and Financial Statement Fraud. The Accounting Review 71(4):443-465.

Beasley,M.S., J.V. Carcello dan D.R. Hermanson. 1999. Fraudulent Financial Reporting 1987-1997 : An Analysis of US Public Companies.Jersey City,NJ :Committee of Sponsoring Organizations of The Treadway Commission (COSO).

Beasley,M.S., J.V. Carcello, D.R. Hermanson, dan P.D Lapides. 2000. Fraudulent Financial Reporting :Consideration of Industry Traits and Corporate Governance Mechanism. Accounting Horizons 14(4):441-454.

Bedard, J., S. Chtourou, L. Courteau. 2004. The Effect of Audit Committee Expertise, Independence, and Activity on Aggressive Earnings Management. Auditing: A Journal of Practice and Theory 23(2):13-35.

Blue Ribbon Committee (BRC). 1999. Report and Recommendations of the Blue Ribbon Committee on Improving the Effectiveness of Corporate Audit Committees. Stamford, CT:BRC.

Chen, Gongmeng, et. al.. 2006. Ownership Structure Corporate Governance, and Fraud; Evidence from China. Journal of Corporate Finance.

Dechow,P.A.,R.G.Sloan, dan A.p.Sweeny. 1996. Causes and Consequences of Earnings Manipulation : An empirical of Firms Subject to Enforcement Actions by The SEC. Contemporary Accounting Research 13 (Spring):1-36.

Deli, D., dan S. Gillan. 2000. On The Demand for Independent and Active Audit Committees. Journal of Corporate Finance 6(4):427-445.

Fama, E. F., dan M. C. Jensen. 1983a. Agency Problems and Residual Claims.Journal of Law and Economics 26: 327-349.

Fama, E. F., dan M. C. Jensen. 1983b. Separation of Ownership and Control. Journal of Law and Economics 26: 301-325.

Farber, D. B. 2005. Restoring Trust after Fraud: Does Corporate Governance Matter?. The Accounting Review: April 2005, Vol. 80, No. 2, pp. 539-561.

Hapsari, Asri Ditha. 2014. Pendeteksian Tingkat Fraud Melalui Faktor Risiko Tekanan Dan Peluang (Studi Kasus Pada Perusahaan Perbankan Periode 2010 - 2012). Naskah Publikasi Ilmiah. Universitas Muhammadiyah Surakarta.

Huang, Hua-Wei, dan Sheela Thiruvadi. 2010. Audit Committee Characteristics and Corporate Fraud.International Journal of Public Information Systems.hal 71-82.

Ikatan Komite Audit Indonesia. 2012. "Komite Audit". http://www.komiteaudit.org, diakses 17 Juni 2012.

Ismiyanti, Fitri dan Chintia Prastichia. 2015. Mekanisme Corporate Governance dan Kecurangan Laporan Keuangan. DeReMa Jurnal Manajemen Vor. 10 No.2.

Owen-Jackson, L.A, D. Robinson dan S.W Shelton. 2009. The Association Audit Committee Characteristics, The Contracting Process and Fraudulent Financial Reporting.American Journal \& Busiiness Vol. 24 No.1.

Januarti, Indira. 2004. Pendekatan dan Kritik Teori Akuntansi Positif.Jurnal Akuntansi dan Auditing Vol. 01 No.01.

Jensen, M. C., dan W.H. Meckling. 1976. Theory of The Firm: Managerial Behavior, Agency Costs and Ownership Structure. Journal of Financial Economics 3:305-360.

Johnson, S.A., dkk. 2005. Executive Compensation and Corporate Fraud. Working paper tidak diterbitkan. Universitas A\&m Texas.

Law, Philip. 2011. Corporate governance and no fraud occurrence in organizations. Managerial Auditing Journal, Vol. 26 Iss 6 pp. $501-518$.

Kusumastuti, S., Supatmi, dan Sastra, P. 2007. Pengaruh Board Diversity terhadap Nilai Perusahaan dalam Perspektif Corporate Governance. Jurnal Akuntansi dan Keuangan. Vol. 9 No. 2, pp. 88-98.

McMullen,D.A. 1996. Audit Committee Performances :An investigation of the Consequences Associated with Audit Committees.Auditing :A Journal of Practice and Theory (Spring):87-103. 
Menon,K., dan J.Williams. 1994. The Use of Audit Committees for Monitoring. Journal of Accounting and Public Policy 13:121-139.

Mustafa dan Meier. 2006. CAP Forum on Forensic Accounting in the Post-Enron World Audit Committees and Misappropriation of Assets: Publicly Held Companies in the United States. Canadian Accounting Perspectives Vol. 5 No. 2 pp. $307-33$.

Nabila, Atia Rahma. 2013. Deteksi Kecurangan Laporan Keuangan dalam Prespektif Fraud Triangle. Skripsi S1, Fakultas Ekonomika dan Bisnis, Univeristas Diponegoro.

Nugraha, Noval Dwi dan Deliza Henny. 2015. Pendeteksian Laporan Keuangan Melalui Faktor Resiko, Tekanan Dan Peluang (Berdasarkan Press Release 0jk 2008-2012). e-Journal Akuntansi Trisakti Volume. 2.

Nurharyanto. 2011. Memahami Fraud dan Melaksanakan Investigative Audit Pada Perusahaan /Korporasi (Teori dan Aplikasinya).Lembaga Pengembangan Fraud Auditing.

Pamudji, S. dan Aprillya Trihartati. 2008. Pengaruh Independensi dan Efektifitas Komite Audit Terhadap Manajemen Laba (Studi Empiris pada Perusahaan Manufaktur yang Terdaftar di BEI). Jurnal Akuntansi dan Auditing Universitas Diponegoro.vol 6 no.1.

Praditia, O., R.. 2010. Analisis Pengaruh Mekanisme Corporate Governance terhadap Manajemen Laba dan Nilai Perusahaan pada Perusahaan Manufaktur yang Terdaftar di Bursa Efek Indonesia (BEI) pada tahun 20052008. Skripsi Akuntansi, Fakultas Ekonomi Universitas Diponegoro.

Rahmanti, Martantya Maudy. 2013. Pendeteksian Kecurangan Laporan Keuangan Melalui Faktor Risiko Tekanan dan Peluang. Skripsi S1, Fakultas Ekonomika dan Bisnis, Univeristas Diponegoro.

Rezaee, Zabihollah. 2007. Corporate Governance Post-Sarbanes-Oxley. Canada: John Wiley \& Sons, Inc.

Rice. 2013. Pengaruh Leverage, Kepemilikan Institusional, Ukuran Dan Nilai Perusahaan Terhadap Tindakan Manajemen Laba. Jurnal Wira Ekonomi Mikroskil.

Rustiarini, Ni Wayan. 2012. Komite Audit Dan Kualitas Audit: Kajian Berdasarkan Karakteristik, Kompetensi, dan Aktivitas Komite Audit. Simposium Nasional Akuntansi XV. Banjarmasin.

Saffudin, A., Z. dan Prasetiono. 2012. Corporate Governance terhadap Praktek Manajemen Laba dan Konsekuensi terhadap Kinerja Keuangan. Jurnal Bisnis dan Ekonomi, Vol. 10, No. 2, Universitas Diponegoro.

Sari, I., C.. 2009. Analisis Struktur Corporate Governance terhadap Manajemen Laba (Studi pada Perusahaan Manufaktur yang listing di BEI). Skripsi Akuntansi, Fakultas Ekonomi Universitas Muhammadiyah Malang.

Sharma. 2004. Board of Director Characteristics, Institutional Ownership, and Fraud: Evidence from Australia. AUDITING: A Journal of Practice \& Theory: September 2004, Vol. 23, No. 2, pp. 105-117.

Skousen, C., Smith, K. R., Wright, C. J. 2009. Detecting and Predicting Financial Statement Fraud: The Effectiveness of the Fraud Triangle and SAS No. 99. Emerald Group Publishing Limited: Advances in Financial Economics vol. 13, hal. 53-81

Soselisa, R., \& Mukhlasin. 2008. Pengaruh Faktor Kultur Organisasi, Manajemen, Strategik, Keuangan dan Auditor Terhadap Kecenderungan Kecurangan Akuntansi: Studi pada Perusahaan Publik di Indonesia. Simposium Nasional Akuntansi XI, 1-33.

Suyanto. 2009. Fraudulent Financial Statement Evidence from Statement on Auditing Standard No.99. Gadjah Mada International Journal of Business, 11(1), 117-144.

Wardhani, Ratna dan Herunata Joseph. 2010. Karakteristik Pribadi Komite Audit dan Praktik Manajemen Laba. Symposium Nasional Akuntansi XIII. Purwokerto.

Watts,R. dan J. Zimmerman. 1986. Positive Accounting Theory.Englewood Cliffs,Nj:Prentice Hall,Inc.

Xie, B., Davidson, W. N. and DaDalt, P. J. 2003. Earnings management and corporate governance: the role of the board and the audit committee. Journal of Corporate Finance, 9(3), 295-316.d-101. 